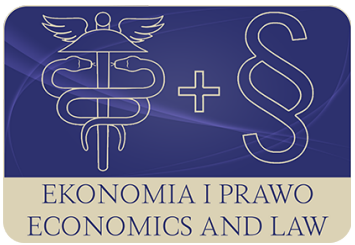

EKONOMIA I PRAWO. ECONOMICS AND LAW

Volume 20, Issue 4, December 2021

p-ISSN 1898-2255, e-ISSN 2392-1625

www.economicsandlaw.pl

EKONOMIA I PRAWO
ECONOMICS AND LAW

ORIGINAL ARTICLE

received 21.01.2021; revised 01.12.2021; accepted 31.12.2021

Citation: Karnowski, J., \& Rzońca, A. (2021). Financing framework for local governments: diagnosis and change proposals. Ekonomia i Prawo. Economics and Law, 20(4), 797-812. https://doi.org/10.12775/EiP.2021.047.

\title{
Financing framework for local governments: diagnosis and change proposals
}

\section{JAKUB KARNOWSKI}

corresponding author

Warsaw School of Economics, Collegium of Economic Analysis, Department of International

Comparative Studies, al. Niepodległości 162, 02-554 Warszawa, Poland

ఐ kubakarn@sgh.waw.pl

(D) orcid.org/0000-0003-4447-4753

\section{ANDRZEJ RZOŃCA}

Warsaw School of Economics, Collegium of Economic Analysis, Department of International

Comparative Studies, Poland

๑arzonc@sgh.waw.pl

orcid.org/0000-0002-8631-2595

\begin{abstract}
Motivation: The best way to widen access to public services at the local level is to increase efficiency of local government spending. However, an increase in efficiency may refer to output or inputs. In the latter case it does not widen access to public services. Moreover, factors conducive to spending efficiency may be detrimental to local cohesion.

Finding a way so that the financing framework for local governments would reconcile the efficiency condition with the conditions of access to public services and local cohesion respectively, is an issue of great importance for economic policy. It seems to be so especially in a country like Poland, where there are large differences in the level of development between regions for historical reasons. These differences, if left accumulating, could easily jeopardize efficiency due to distorted capital flows, not to mention political tensions they may cause.

Aim: The article aims at identifying basic features of the financing framework for local governments in Poland that hinder efficiency of their spending and at proposing feasible
\end{abstract}


changes to that framework that would improve the efficiency but not at the expense of local cohesion or access to public services.

Results: The article argues that the financing framework of local governments in Poland would better meet conditions of both efficiency and access to public services, if local governments relied mostly on revenues from income taxes instead of transfers from the central government, and some elements of tax competition between local authorities, although restricted to PIT-free allowance, were introduced. Such a shift in local governments revenue composition would not weaken local cohesion, if it was accompanied by an appropriate solidarity subvention financed by the richest voivodeship and the central government, and non-recurring central government revenues were allocated to investments exceeding financial capacity of local governments.

Keywords: local governments; decentralization; transfers; tax competition; spending efficiency; local cohesion; access to public services

JEL: O57; H79; H72; H70; H7l

\section{Introduction}

To provide broad access to public services, local governments need not only wide competences but also enough money to fulfil their tasks. Those tasks should be performed with possibly tight cost control (Besley \& Coate, 2003). However, the removal of unnecessary costs must not undermine local cohesion (Shah, 2006). If differences in local living standards were to grow, they could easily lead to various inefficiencies (Cai \& Treisman, 2005), for example due to political tensions they may induce. Such tensions are unlikely to be conducive to efficiency. They rather jeopardised it, especially if they appeared as a consequence of pro-efficiency changes (cf. Mueller et al., 2017). All this shows how important financing framework for local governments may be from economic, social and political perspective.

The article diagnoses that framework in Poland in terms of its possible impact on local spending efficiency and proposes some changes which meet the following three conditions. Firstly, the proposed changes are aimed at helping the local governments to carry out their tasks fully (access to public services condition). Secondly, if they were introduced, they would encourage the local authorities to manage the financial resources that are at their disposal as efficiently as possible (efficiency condition). Efficiency is understood broadly here and relates to both output and inputs. Output efficiency takes into account how a certain amount of public money is spent. Input efficiency focuses on how much is spent to achieve a given goal. If these two concepts of efficiency are envisaged together, they allow setting public spending as close as possible to the level that maximises social welfare (cf., e.g. Mandl et al., 2008). Thirdly, in the proposed changes to the framework, the condition of equalisation of differences in the level of development between individual regions (cohesion condition) is as important as the efficiency condition. We place an emphasis on the cohesion condition mainly due to the source of development differences in Poland. To a large extent, they are not based on objective premises (geography in par- 
ticular) but history. Therefore, their equalisation is possible without a significant loss of efficiency and, consequently, of social welfare at the national level. Recall also that irrespective of their nature, these differences could easily lead to political tensions jeopardizing efficiency, if they were left accumulating.

The method we apply is descriptive and consists of three steps. They are undertaken in separate sections (numbered from two to four). First, we start with a brief survey of the literature on effects of (de-)centralisation of public finances (see, e.g. Bartolini et al., 2018; Bukowska \& Siwińska-Gorzelak, 2019; de Mello, 2000; Eyraud \& Lusinyan, 2011; Köppl-Turyna \& Pitlik, 2018; Lago-Peñas et al., 2019; Mueller et al., 2017; Rodden, 2005). We survey the literature in order to define basic features of financing framework for local governments that favour, or conversely, hinder efficiency of their spending. Second, based on the conclusion from the survey, we analyse regulations on the financing framework for local governments and basic data on their finances in Poland. The analysis makes a bird's eye diagnosis of that framework in terms of its effects on efficiency of spending. The data inspection helps determine whether possibly limited changes to the framework could address its weaknesses. Third, we propose some feasible changes to the framework which would favour the efficiency, but not at the expense of the regional cohesion or access to public services. The three-step analysis is followed by the section four which concludes.

\section{The framework for financing local governments in the light of previous research}

The main problem in constructing the financing framework for local governments in terms of its impact on the efficiency of public money management on the one hand and the differences in the level of development between individual regions of the country, on the other, is to determine the degree of (de-) centralisation of public revenues as compared to the (de-)centralisation of public spending. The extent to which local governments' expenditure should be financed from their revenues (and how much freedom they should have in shaping the parameters influencing those revenues) is analysed in economic terms from two main perspectives:

- public finance theory,

- political economics.

Public finance theory assumes that the central government's task should be to eliminate (or at least mitigate) market failures that local authorities cannot cope with (or which may even be the source of). It provides justification for the financing of local government expenditure with transfers from the central budget. However, at the same time, it points out that full equality of public revenues in all local governments would discourage them from growth enhancing activities extending the tax base. Therefore, it is emphasised that transfers should only provide a certain standard of public service and that local authorities should retain a large proportion of the public revenues generated by their 
actions (Weingast, 2009). Simultaneously, differences in price levels between poor and rich parts of the country should be taken into account when determining the volume of transfers (Chen \& Rosenthal, 2008). If one does not consider that prices in rich regions are usually higher than in poor ones, one runs the risk of setting transfers at too high a level (increasing the quality of public services in poor parts of the country above their quality in rich regions). An additional reason justifying the reduction of transfers raised in public finance theory is that they lower the assessment of expenditure costs made at the level of local governments (below their actual social costs) and, as a result, they cause an increase in public expenditure above the level that maximises social welfare. At the same time, they weaken local governments' incentives to increase the efficiency of their activities, including the development of innovative ways of providing public services (Bahl \& Linn, 1992).

The basic argument in favour of financing local governments' expenditures with transfers, put forward in the theory of public finance, is to prevent large differences in the level of development to arise between individual regions of the country. It is pointed out that the absence of such transfers enables rich local authorities to collect lower taxes for public services of a specific quality or to provide higher quality public services at a given level of taxation. As a result, rich local governments attract more investment than poor ones, which deepens the differences in the level of development between individual regions of the country (see, e.g. Cai \& Treisman, 2005). The capital flows from poor to rich parts of the country are not effective as they don't reflect the natural differences in factors productivity between regions of the country. It is argued that only with fully harmonised tax rates can these flows be effective (Boadway, 1979). It is also argued that the more freedom local governments have in shaping the parameters affecting public revenues, the higher the transfers to poor local governments should be to mitigate the distortions in capital flows caused by tax differences (Shah, 2006).

A way to deal with ineffective capital flows from poor to rich parts of the country is to limit local governments' freedom in shaping their revenues to only those parameters that affect labour rather than capital to the greatest extent possible. Flows of people (especially those who are not wealthy, i.e., without capital) from poor parts of the country to the rich parts are an essential mechanism for equalising per capita income (Barro \& Sala-i-Martin, 1991).

The second argument favouring the financing of local governments' expenditures by means of transfers is that of external effects - expenditures incurred by one local government may cause effects in other local governments (Cooter \& Siegel, 2010). These effects are particularly related to expenditure on education, infrastructure and environmental protection. However, there is a practical problem with identifying these effects correctly. In addition, local authorities can deal with them without the intermediation of central authorities by concluding appropriate agreements between themselves (Myers, 1990). 
The third argument in favour of transfers, raised in public finance theory, is to protect local governments from the effects of idiosyncratic shocks, i.e., that hit a single local government (Sanguinetti \& Tommasi, 2004). However, empirical studies, including those carried out in countries where transfers have a high share in financing the expenditure of local governments, do not confirm that this safeguard is effective (Buettner, 2002).

The second approach, namely political economics, points out that not only the economic agents but also the authorities (at every level) act primarily in their interest (Brennan \& Buchanan, 1980). In order for the interest of the authorities to be as close as possible to the interest of the economic agents, the authorities must have as hard budget constraints as possible, tying public expenditure (and its benefits, including political benefits) with the tax burden (and the resulting costs, including political costs) imposed on agents that choose authorities. In this approach, basing the financing of local governments' expenditures on their revenues is a mechanism for disciplining both local and central authorities, forcing them to act in the interest of their inhabitants. It means that when local authorities are deciding on a given expense, they cannot ignore the cost of the taxes that finance it because they have to raise them automatically; in turn, central authorities have limited possibilities to impose taxes on their opponents (who may be concentrated in certain areas of the country) and finance their supporters from these taxes (Besley \& Coate, 2003).

By softening the budget constraint, transfers weaken this mechanism. Local authorities can concentrate on their interests. They do not have to compete with each other in creating the best possible conditions for the development of business entities, as they do not decide on their spending capacity, only the favour of central authorities does. The weaker their efforts to expand their tax base, the stronger the (negative) link between the transfers they receive from the central budget and their tax income (or, more generally, per capita income in a given area). At the same time, the resilience of local governments to shocks may also weaken because they may rely on the central government as they have no special incentives to take care of the resilience by themselves. Finally, fiscal discipline is also weakening (Mueller et al., 2017). The more the central government finances the local authorities, the higher the political costs it faces if it refuses to support a unit in financial difficulties (Rodden, 2005). The more complicated the construction of transfers is, the more serious their negative effects become. The high complexity of transfers limits the ability of voters to evaluate public services provided by local governments (Kotsogiannis \& Schwager, 2008).

Empirical research on the framework for financing local governments has led to the following conclusions:

1. The size of the transfers is determined more by political criteria than by technical criteria. This even applies to countries perceived as free from corruption (with which manifestations of political corruption should go hand in hand), such as Norway (Sørensen, 2003). 
2. Transfers increase local government expenditure and total public expenditure, especially if they cover a fixed percentage of local government expenditure for a given purpose (Ashworth et al., 2013; Dahlberg et al., 2008; Eyraud \& Lusinyan, 2011).

3. Transfers do not induce local governments to reduce local taxes and may even increase them (Buettner, 2006; Egger et al., 2010).

4. Transfers weaken the fiscal discipline of local governments and the whole general government, especially if they are accompanied by high decentralisation of public expenditure and large differences in the level of development between different parts of the country (cf., e.g. Bartolini et al., 2018; Bukowska \& Siwińska-Gorzelak, 2019; de Mello, 2000; Eyraud \& Lusinyan, 2011; Köppl-Turyna \& Pitlik, 2018; Lago-Peñas et al., 2019; Mueller et al., 2017; Rodden, 2005).

5. Transfers, including, in particular, their link to per capita income, reduce the efficiency of local government spending (Boetti et al., 2012; Christl et al., 2020; Kalb, 2010).

6. A large difference in the degree of decentralisation of public expenditure and revenues weakens GDP per capita growth (Gemmell et al., 2013).

\section{The current financing framework for local governments ${ }^{1}$}

Considerations about the financing framework for local governments in Poland have already occurred in literature (see, e.g. Bukowska \& Siwińska-Gorzelak, 2019 or Kopańska et al., 2018).

According to the widespread classification, one should distinguish three basic models of financing local government units: (1) decentralised, (2) centralised and (3) mixed - depending on the role of own revenues and central government transfers.

Although the scope of reliance on transfers varies across different kind of local government units, the overall system of their financing should be perceived as the mixed one, mainly due to the municipalities, relying upon their own revenues in a non-negligible degree (Sekuła \& Śmiechowicz, 2018). In 2021, the share of local government units in revenues from personal income tax (PIT) is $50.08 \%$, including municipalities $38.23 \%$, districts $10.25 \%$ and voivodeships $1.6 \%$. In turn, the share of local government units in revenues from corporate income tax (CIT) is $22.86 \%$, including voivodeships $14.75 \%$ and municipalities $6.71 \%$.

Local governments do not influence the parameters of PIT and CIT taxes. There are no elements of tax competition between local governments that would favour the efficiency of public money management.

Public expenditure in Poland is more decentralised than public revenues. As a result, transfers from the central government are a more important source

${ }^{1}$ Due to the limited size of the text, authors did not refer to cities upon the rights of districts, which, should also be thoroughly discussed. 
of financing local governments' expenditures than their revenues from PIT and CIT. The transfers mainly consist of the general subvention and grants.

\subsection{General subvention}

According to the Act on the income of local government units (2003), the general subvention consists of four main parts:

- educational - which goes to municipalities, districts and voivodeships;

- compensatory - which goes to municipalities and districts;

- balancing - which aids the budgets of local government units of all levels;

- the regional - for voivodeships only.

About 22\% of local government revenues in 2019 came from the general subvention. Its vast majority is allocated to the educational part (77\%). Its second highest part is the compensatory part.

Criteria for distribution vary across different kinds of local government units and there are specifically described in the abovementioned Act.

The overall sum of general subvention for the 2019 are compared in the Tablel.

\subsection{Grants}

In addition, the local governments' budgets may also be supplied with grants. Those grants may be used to co-finance local government tasks and to finance tasks in the field of central government administration, other tasks commissioned by law, as well as tasks implemented on the basis of agreements with government administration. In 2019 they reached PLN 60.1 bln (not including grants for co-financing of EU programs and specific reserves for co-financing, mainly for investments and road maintenance). Over $99 \%$ of grants for local governments come from the budgets of voivodes.

As for 2019, the vast majority of grants (over $86 \%$ in 2019) went to municipalities. More than $93 \%$ of grants were allocated to family tasks, including, in particular, the payment of the 500 plus allowance and family benefits.

The districts receive about $11 \%$ of the grants, which finance mainly central government administration tasks delegated to districts.

A traceable share of the grants goes to the voivodeships. Approximately $57 \%$ of them are allocated to a single purpose, i.e., subsidies for bus transport for the application of the discounts applicable under the Act.

\subsection{General observations}

The analysis of the current framework for financing local governments in comparison with the previously presented conclusions from the literature, on the relations between this framework and the efficiency of public money management and cohesion between individual regions of the country, indicates its three major weaknesses: 
1. Local governments in Poland rely more on transfers from central government than their own revenues. Such composition of their revenues increases their vulnerability to political bargaining at the central level, not to say political corruption, and reduces the efficiency of their spending.

2. There is no elements of tax competition between local authorities, which additionally hampers efficiency of local government spending.

3. The general subvention received by local governments is complicated, which further hinders efficiency, in particular through weakening of their incentives to expand tax base.

However, public finances in Poland have some features that help find a feasible solution to possible inefficiencies. In particular, a similar scale of the revenues to the central government budget from PIT, on the one hand and, the general subvention to municipalities on the other, makes it easier to link the increase in the share of municipalities in revenues from PIT tax with the cuts in transfers to local governments. The correlation coefficient between the increase in municipalities revenues from PIT tax, if the total central government revenues from this tax were to be allocated to their budgets, and the general subvention which goes to them is high and amounts to 0.92 . If all the central government revenues from PIT were to go to the municipalities, the amount of their revenues in 2021 would increase by PLN 68.1 bln. This increase is only slightly higher from this year general subvention to municipalities and cities with district rights.

Similar facilitation is the significantly larger scale of voivodes' budgets and grants to local governments financed by these budgets than the central government revenues from CIT tax. If all central government revenues from CIT were to go to self-government voivodeships, the amount of their revenues would increase by PLN $39.6 \mathrm{bln}$. This increase is considerably lower than the grants allocated to local governments from the budgets of voivodes, which in 2021 are to amount to PLN 63.8 bln.

\section{Desired changes in the framework for financing local governments ${ }^{2}$}

As indicated in the introductory remarks the financing framework for local government units should meet three conditions:

- help these units to accomplish their tasks fully (access to public services condition);

- encourage the local authorities to manage the financial resources that are at their disposal as efficiently as possible (efficiency condition);

- mitigate historical differences in development between individual regions in Poland (cohesion condition).

It follows from the previous sections that the current framework is not conducive to efficiency in local government spending. While designing changes that

\footnotetext{
${ }^{2}$ All sums are based upon own calculations.
} 
would promote efficiency is not very difficult, ensuring that they simultaneously widen access to public services and strengthen local cohesion is a more challenging task. It is impossible to boil such changes down to one general point. We summarize them in nine instead.

First, the central government should, as in Switzerland, draw its revenues mainly from indirect taxes, while all income tax revenues should remain where the people who pay it live. Taking into account the feasibility of such a change, the PIT should primarily supply the municipalities and replace the general subvention. In turn, the CIT should go mainly to voivodeships' budgets. It would be the primary financing source for the tasks assigned to them that are currently carried out by voivodes. The share of municipalities in revenues from PIT would increase to $88.15 \%$, if the shares of districts and voivodeships in these revenues didn't change. However, the shift of all revenues from PIT to municipalities could be considered. Given that path dependence also applies to public finances, it would be less feasible, as it would require much deeper changes in the financing framework than those proposed in this article. The share of voivodeships in revenues from CIT would increase to $91.89 \%$ provided that the shares of municipalities and districts in these revenues didn't change. The shift of all revenues from CIT to the voivodeships is not considered here for feasibility reasons mentioned above. Nevertheless, even if the municipalities and districts retain their share in CIT revenues, giving them some freedom to decide on the parameters of this tax (to the extent that it affects only their revenues and not the revenues of the voivodeship) should be taken into consideration. We will return to the problem of tax competition in point three below.

In 2021 the local governments are to receive a half of PIT revenues $(50.08 \%)$ and less than a quarter of CIT revenues (22.86\%). If the changes proposed above entered into force in 2021, local authorities would decide not about $68.3 \mathrm{bln}$ of PIT revenues but about $136.4 \mathrm{bln}$, and not about $10.9 \mathrm{bln}$ of CIT revenues but about 47.8 bln. By leaving most of the revenues from PIT in municipalities, people would have greater awareness and control over what their taxes are spent on. By leaving most of the revenues from CIT in voivodeships, entrepreneurs would have a stronger sense that the conditions in which they operate depend on the taxes they pay. On the one side, taxpayers' money would be spent more economically and wisely. On the other side, there would be less tax evasion, and the collection of taxes could be less costly than today. Note that the cost of tax collection in Poland in relation to the amount of tax revenues is among the highest in OECD countries.

The central government would lose up to PLN 1.2 bln if it replaced the general subvention for municipalities by increasing their share in PIT revenues to $88.15 \%$. At the same time, this is the minimum total scale of benefits that municipalities from the proposed changes in the framework for their financing would achieve. Furthermore, apart from Mazowieckie, in no voivodeship the additional revenues from increasing the share of the voivodeships in the CIT revenues exceed the budget that the voivodes have today. The new framework 
for financing voivodeships could, therefore, be neutral for the central government budget. If it was not, this would be because of cohesion issues discussed below (see points 5-9). These issues could be addressed by the so-called solidarity subvention, whose cost would be incurred by Mazoieckie voivodeship and central government budget. The larger the share of the subvention covered by the Mazowieckie voivodeship, the closer the proposed changes to the financing framework would be to neutrality.

Second, local governments should have broad autonomy in deciding how to spend taxpayers' money but should not have the right to deviate from nationally established public service quality standards, since efficiency of local government spending should not be improved in expense of local cohesion. The standards should relate in particular to the quality of education which is of crucial importance for cohesion (see, e.g. OECD, 2010). The proposal of broad autonomy in spending combined with standards set at the central level is modelled on Sweden.

Third, local governments should have the right to refund part of the tax money to the residents - as is the case of Switzerland and Sweden. This step would be necessary in order to better meet efficiency condition. As the research described in the section two shows, significant improvement in the efficiency of local government spending would hardly be possible with no elements of tax competition between local authorities.

Fourth, given the cohesion condition, this competition should be shaped so that it prevents the formation of rich enclaves, separating from the rest of the country. Recall that the public finance theory suggests that violation of the cohesion criterion would jeopardize compliance with the efficiency condition. Poland seems not as ready as Switzerland in allowing competition in tax rates between local authorities because, for historical reasons, there are large differences in the level of development between different parts of Poland. In order to reduce these differences, local governments should be free to compete not with PIT rates, but only with tax-free allowance. The competence of municipalities should be to increase the allowance relative to the basic amount set out at the national level. Such a solution would be most beneficial for inhabitants with low incomes. It would also help to increase economic activity rate, as labour supply of low earners is most sensitive to taxation (see, e.g. Disney, 2000). The importance of such a change is increased by the rapid ageing of the population in Poland.

Fifth, the access to public services condition and the cohesion condition imply that more money should go to all units (each municipality, district and voivodeship). Those in more developed parts of the country would benefit from the increased share in revenue from income taxes. Revenue of those in less developed regions should be supplemented by some kind of solidarity subvention, which would replace the general subvention. The budgets of those municipalities, which are covered by various forms of nature protection, could be additionally subsidised by an ecological subvention as compensation, for de- 
velopment constraints on the one hand and positive externalities, on the other hand, from which other parts of the country benefit.

Sixth, for local government revenues to increase in every part of the country, including in villages where many residents work in agriculture and do not pay PIT, the solidarity subvention should be sufficiently wide. In particular, it should complement the revenues of at least 1903 municipalities. In such a number, replacing the general subvention by increasing the share of municipalities in PIT revenues would mean a loss of revenues if the introduction of a solidarity subvention did not accompany it. This loss would amount to PLN 10.386 bln in total and should be compensated. It sets a minimum total solidarity subvention. Its costs would be slightly smaller if alternative methods of determining it were applied. Those alternative methods include compensating the municipalities for losses up to the amount of the current median of: (l) total revenue (domestic and foreign), (2) domestic revenue, or (3) a general subvention. The solidarity subvention would then amount to (1) PLN 9.882 bln, (2) PLN 9.906 bln, or (3) PLN 8.599 bln respectively. However, unlike the first method, the alternative methods have no significant advantage - they do not ensure that all municipalities would benefit from the new financing framework once it is in place (however, it would be their lion's share).

Seventh, to meet the cohesion condition, the solidarity subvention should be financed both by the central government and from income taxes paid locally in more developed parts of the country. Without the participation of the central government in the financing of the solidarity subvention, the stimulation of local governments to expand their tax base would be limited. In turn, without the participation of local authorities, it would be difficult to ensure cohesion between individual regions of the country, including building a community. The increase in municipalities' revenues from increasing the share in PIT revenues is negatively correlated with the current amount of total subvention per capita. As it comes to the part covered by the central government, the solidarity subvention should be related to VAT receipts. Because of this, its size would automatically increase along with the increase in Poles' wealth and their purchases. The less developed parts of the country would have a guarantee of steadily growing revenues and thereby could provide access to public services of ever higher quality. At the same time, they would not, as is the case today, be punished by cutting subvention for efforts to increase residents' income and, therefore, the taxes they pay to the local budget. They would also be able to compete with PIT-free allowance with more developed regions. This is because its increase would deplete a much smaller part of their budgets than in more developed regions.

Eighth, in the part covered by the richest local governments, the solidarity subvention should serve a specific purpose, above all education. Providing for all children, no matter where they live, access to a decent public school is among the most effective ways to eliminate historical differences (see, e.g. OECD, 2010). Structured like this, the solidarity subvention in unlikely to cause a feel- 
ing of harm to the richest local governments, which could easily arise if there were no tangible effects of aid provided to the less developed parts of the country.

Ninth, historical differences could also be addressed by an increase in local investments. Local governments should gain new funding sources for investments exceeding their financial capacity, for example a revitalisation fund for cities, and a development fund for villages. These funds could be supplied with European money and non-recurring central government revenues (in particular, windfalls from the central bank). Now such revenues are immediately spent.

\section{Conclusions}

The financing framework for local governments in Poland hardly promotes the efficiency of their spending. This calls for changes in that framework. However any improvement in efficiency would unlikely be permanent, if it curbed access to public services and undermined local cohesion. Thus, apart from the efficiency condition, the changes should also meet two other conditions. Namely, they should help local governments fulfil the tasks entrusted to them (the access to public services condition) and, at the same time, ensure the reduction of historical development differences across regions (the cohesion condition).

Based on survey of the literature, analysis of regulations and data inspection one may argue that the financing framework of local governments in Poland would better meet conditions of both efficiency and access to public services, if local governments relied mostly on revenues from income taxes instead of transfers from the central government, and some elements of tax competition between local authorities, although restricted to PIT-free allowance, were introduced. Such a shift in local governments revenue composition would not weaken local cohesion, if it was accompanied by an appropriate solidarity subvention. The subvention should be covered by both the richest voivodeship and the central government and mainly finance education, which is particularly conducive to cohesion. Allocation of non-recurring central government revenues to investments exceeding financial capacity of local governments would also be of help.

\section{References}

Ashworth, J., Galli, E., \& Padovano, F. (2013). Decentralization as a constraint to Leviathan: a panel cointegration analysis. Public Choice, 156(3), 491-516. https://doi.org/10.1007/s11127-012-9962-8.

Bahl, R.W., \& Linn, J.F. (1992). Urban public finance in developing countries. Oxford University Press.

Barro, R.J., \& Sala-i-Martin, X. (1991). Convergence across states and regions. Brookings Papers on Economic Activity, 1, 107-182. https://doi. org/10.2307/2534639. 
Bartolini, D., Sacchi, A., Salotti, S., \& Santolini, R. (2018). Fiscal decentralization in times of financial crises. CESifo Economic Studies, 64(3), 456-488. https://doi.org/10.1093/cesifo/ifx008.

Besley, T., \& Coate, S. (2003). Centralized versus decentralized provision of local public goods: a political economy approach. Journal of Public Economics, 87(12), 2611-2637. https://doi.org/10.1016/S0047-2727(02)00141-X.

Boadway, R.W. (1979). Public sector economics. Little, Brown.

Boetti, L., Piacenza, M., \& Turati, G. (2012). Decentralization and local governments' performance: how does fiscal autonomy affect spending efficiency. FinanzArchiv: Public Finance Analysis, 68(3), 269-302 https://doi. org/10.1628/001522112x653840.

Brennan, G., \& Buchanan, J.M. (1980). The power to tax: analytical foundations of a fiscal constitution. Cambridge University Press.

Buettner, T. (2002). Fiscal federalism and interstate risk sharing: empirical evidence from Germany. Economics Letters, 74(2), 195-202. https://doi. org/10.1016/s0165-1765(01)00548-1.

Buettner, T. (2006). The incentive effect of fiscal equalization transfers on tax policy. Journal of Public Economics, 90(3), 477-497. https://doi. org/10.1016/j.jpubeco.2005.09.004.

Bukowska, G., \& Siwińska-Gorzelak, J. (2019). Can higher tax autonomy enhance local fiscal discipline: evidence from tax decentralization in Poland. Publius: The Journal of Federalism, 49(2), 299-324. https://doi.org/10.1093/ publius/pjy024.

Cai, H., \& Treisman, D. (2005). Does competition for capital discipline governments: decentralization, globalization, and public policy. American Economic Review, 95(3), 817-830. https://doi.org/10.1257/0002828054201314.

Chen, Y., \& Rosenthal, S.S. (2008). Local amenities and life-cycle migration: do people move for jobs or fun. Journal of Urban Economics, 64(3), 519-537. https://doi.org/10.1016/j.jue.2008.05.005.

Christl, M., Köppl-Turyna, M., \& Kucsera, D. (2020). Determinants of public sector efficiency: decentralization and fiscal rules. Kyklos, 73(2), 253-290. https://doi.org/10.1111/kykl.12224.

Cooter, R.D., \& Siegel, N.S. (2010). Collective action federalism: a general theory of article I, section 8. Stanford Law Review, 63(1), 115-185.

Dahlberg, M., Mörk, E., Rattsø, J., \& Ågren, H. (2008). Using a discontinuous grant rule to identify the effect of grants on local taxes and spending. Journal of Public Economics, 92(12), 2320-2335. https://doi.org/10.1016/j. jpubeco.2007.05.004.

de Mello, L.R.Jr. (2000). Fiscal decentralization and intergovernmental fiscal relations: a cross-country analysis. World Development, 28(2), 365-380. https://doi.org/10.1016/S0305-750X(99)00123-0.

Disney, R. (2000). The impact of tax and welfare policies on employment and unemployment in OECD countries. IMF Working Paper, 164, 1-42. https://doi.org/10.5089/9781451857986.001. 
Egger, P., Koethenbuerger, M., \& Smart, M. (2010). Do fiscal transfers alleviate business tax competition: evidence from Germany. Journal of Public Economics, 94(3-4), 235-246. https://doi.org/10.1016/j.jpubeco.2009.10.002.

Eyraud, L., \& Lusinyan, L. (2011). Decentralizing spending more than revenue: does it hurt fiscal performance. IMF Working Paper, 1l(226), 1-33. https:// doi.org/10.5089/9781463904944.001.

Gemmell, N., Kneller, R., \& Sanz, I. (2013). Fiscal decentralization and economic growth: spending versus revenue decentralization. Economic Inquiry, 51(4), 1915-1931. https://doi.org/10.1111/j.1465-7295.2012.00508.x.

Kalb, A. (2010). The impact of intergovernmental grants on cost efficiency: theory and evidence from German municipalities. Economic Analysis and Policy, 40(1), 23-48. https://doi.org/10.1016/S0313-5926(10)50002-X.

Kopańska, A., Kula, G., Siwińska-Gorzelak, J., Bukowska, G., \& Młochowska M. (2018). Autonomia fiskalna i jej wptyw na dziatania samorządów. Scholar.

Köppl-Turyna, M., \& Pitlik, H. (2018). Do equalization payments affect subnational borrowing: evidence from regression discontinuity. European Journal of Political Economy, 53, 84-108. https://doi.org/10.1016/j. ejpoleco.2017.07.002.

Kotsogiannis, Ch., \& Schwager, R. (2008). Accountability and Fiscal Equalization. Journal of Public Economics, 92(12), 2336-2349. https://doi. org/10.1016/j.jpubeco.2007.12.013.

Lago-Peñas, S., Martinez-Vazquez, J., \& Sacchi, A. (2020). Fiscal stability during the Great Recession: putting decentralization design to the test. Regional Studies, 54(7), 919-930. https://doi.org/10.1080/00343404.2019.163783 6.

Mandl, U., Dierx, A., \& Ilzkovitz, F. (2008). The effectiveness and efficiency of public spending. European Economy: Economic Papers, 301, 1-36. https:// doi.org/10.2765/22776.

Mueller, S., Vatter, A., \& Arnold, T. (2017). State capture from below: the contradictory effects of decentralisation on public spending. Journal of Public Policy, 37(4), 363-400. https://doi.org/10.1017/S0143814X15000355.

Myers, G.M. (1990). Optimality, free mobility, and the regional authority in a federation. Journal of Public Economics, 43(1), 107-121. https://doi. org/10.1016/0047-2727(90)90053-K.

OECD. (2010). Improving health and social cohesion through education. https:// doi.org/10.1787/9789264086319-en.

RM. (2020). Sprawozdanie z wykonania budżetu państwa za okres od 1 stycznia do 31 grudnia 2019: informacja o wykonaniu budżetów jednostek samorząu terytorialnego. Retrieved 17.11.2020 from https://www.gov.pl/web/finanse/ sprawozdanie-roczne-za-2019-rok.

Rodden, J. (2005). Hamilton's paradox: the promise and peril of fiscal federalism. Cambridge University Press. https://doi.org/10.1017/CBO9780511616075. 
Sanguinetti, P., Tommasi, M. (2004). Intergovernmental transfers and fiscal behaviour insurance versus aggregate discipline. Journal of International Economics, 62(1), 149-170. https://doi.org/10.1016/S0022-1996(03)00045-X.

Sekuła, A., \& Śmiechowicz, J.(2018). Model finansowania samorządu terytorialnego w Polsce. Studia Ekonomiczne: Zeszyty Naukowe Uniwersytetu Ekonomicznego w Katowicach, 358, 212-220.

Shah, A. (2006). A practitioner's guide to intergovernmental fiscal transfers. Policy Research Working Paper, 4039, 1-51.

Sørensen, R.J. (2003). The political economy of intergovernmental grants: the Norwegian case. European Journal of Political Research, 42(2), 163-195. https://doi.org/10.1111/1475-6765.00079.

Ustawa z dnia 13 listopada 2003 r. o dochodach jednostek samorządu terytorialnego [Act of November 13, 2003 on the income of local government units) (Dz.U. 2003 nr 203 poz. 1966) (Poland).

Weingast, B.R. (2009). Second generation fiscal federalism: the implications of fiscal incentives. Journal of Urban Economics, 65(3), 279-293. https://doi. org/10.1016/j.jue.2008.12.005.

\section{Acknowledgements}

Author contributions: authors have given an approval to the final version of the article. Authors contributed to this work equally.

Funding: this research was fully funded by the author's own sources. 


\section{Appendix}

Table 1.

Amount of certain parts of general subvention in 2019 (in billion PLN)

\begin{tabular}{lcccc}
\hline \multicolumn{1}{c}{ Specification } & Educational part & Compensatory part & Balancing part & Regional part \\
\hline municipalities & 22.0 & 8.0 & 0.3 & - \\
districts & 8.6 & 2.3 & 0.7 & - \\
voivodeships & 0.6 & - & 1.4 & 0.5 \\
\hline
\end{tabular}

Source: Own preparation based on RM (2020). 